\title{
Profil usia dan pekerjaan pasien kanker payudara NST berdasarkan fenotipe molekuler her-2
}

\author{
Age and occupational profile of NST breast cancer patients based on her-2 \\ molecular phenotype \\ Yuni Prastyo Kurniati ${ }^{1 *}$, Khonsa ${ }^{2}$ \\ ${ }^{1}$ laboratorium Patologi Anatomi Fakultas Kedokteran Universitas Muhammadiyah Surakarta,Surakarta dan 57169, Indonesia \\ ${ }^{2}$ Fakultas Kedokteran Universitas Muhammadiyah Surakarta,Surakarta dan 57169, Indonesia \\ ${ }^{1}$ ypk134@ums.ac.id*, ${ }^{2}$ khonsa281@gmail.com \\ *corresponding author \\ Tanggal Submisi: 15 Oktober 2020, Tanggal penerimaan: 21 September 2020
}

\begin{abstract}
Abstrak
Kanker payudara menjadi penyebab utama kematian wanita. Sebagian besar sebagai NST (No Special Type). Pemeriksaan gambaran, derajat histologi, stadium, reseptor hormonal dan status Her-2 sebagai standar diagnosis, prognosis dan prediksi NST. Tujuan penelitian ini untuk melihat sebaran Fenotipe molekuler Her-2 berdasarkan kelompok usia dan pekerjaan pada NST. Jenis penelitian ini adalah analitik observasional dengan pendekatan cross sectional menggunakan teknik pengambilan sampel Purposif Sampling sebanyak 106 sampel. Hasil penelitian menunjukkan Usia terbanyak kanker payudara > 50 tahun dengan 50,8\% memiliki HER-2 positif. Jenis pekerjaan terbanyak sampel berisiko rendah dengan 57,8\% memiliki HER-2 negatif. Kesimpulan penelitian ini Usia terbanyak sampel > 50 tahun dengan jenis pekerjaan terbesar beresiko rendah. Sementara 50,8\% sampel memiliki HER-2 positif.
\end{abstract}

Kata kunci: her-2; kanker; payudara; pekerjaan; usia

\begin{abstract}
Introduction: Breast cancer is the leading cause of death for women. Mostly as NST. Examination of the picture, histology grade, stage, hormonal receptors and Her-2 status as standard diagnosis, prognosis and prediction of NST. Objective: To see the distribution of Her-2 molecular phenotypes based on age groups and occupation at NST. Methods: This was an observational analytic study with a cross sectional approach using purposive sampling. Results: Most of the breast cancer age was more than 50 years with 50.8\% having positive HER-2. Most types of work in the sample are low risk, with 57.8\% having negative HER-2. Conclusion: Most of the sample age is more than 50 years with the largest low-risk type of work. Meanwhile $50.8 \%$ of the samples had positive HER2.
\end{abstract}

Keywords: age; breast cancer; her-2; occupation 


\section{PENDAHULUAN}

Insidensi dan kematian akibat kanker berkembang pesat di seluruh dunia. (Fenga, 2016). Tahun 2012, sekitar 8,2 juta kematian disebabkan oleh kanker (Data Riset Kesehatan Dasar, 2015). Temuan kasus baru kanker payudara masih menempati urutan kedua dari seluruh macam kanker pada tahun 2018 (Fenga, 2016). Kanker payudara diakui sebagai masalah kesehatan masyarakat yang utama di negara-negara berkembang (Balekouzou, et al., 2017). Penyakit ini masih menjadi penyebab utama kematian kanker pada Wanita. Benua Asia dengan jumlah populasinya mewakili 59\% populasi global, memiliki risiko terkena kanker payudara terbesar dengan persentase 39\% penderita baru, serta sekitar 44\% berujung pada kematian (Global Facts and Figures, 2015). Berdasarkan data Kementrian Kesehatan RI, penyakit kanker serviks dan kanker payudara merupakan penyakit dengan prevalensi tertinggi di Indonesia pada tahun 2013, yaitu kanker serviks sebesar 0,8 \%o dan kanker payudara sebesar 0,5\% atau 61.682 jumlah kasus (Data Riset Kesehatan Dasar, 2015). Prevalensi kasus kanker payudara di Provinsi Jawa Tengah mengalami peningkatan dari $0.02 \%$ pada tahun 2005 menjadi 0.04\% pada tahun 2006. Berdasarkan Profil Kesehatan Provinsi Jawa Tengah Tahun 2008, wilayah di Jawa Tengah dengan angka kejadian kanker payudara tertinggi berada di Semarang sebanyak 4215 kasus, diikuti Surakarta sebanyak 3829 kasus, Sukoharjo sebanyak 771 kasus, dan Kudus sebanyak 456 kasus (Anggorowati, 2013).

Kanker payudara dapat dikategorikan secara luas ke dalam kelompok kanker in situ dan Invasive (Hatem et al, 2016). Sebagian besar kanker payudara Invasive tidak memiliki ciri khas dan digolongkan sebagai No Special Type atau NST, yaitu sekitar 40-75\% dari seluruh kanker payudara. NST juga kadang-kadang disebut NOS (tidak ditentukan). Dahulu disebut sebagai kanker duktus Invasive. (Hutagalung dkk, 2014; Cancer Research, 2016). Secara umum yang dimaksud dengan Invasive carcinoma of no special type adalah kanker yang tidak dapat disubklasifikasikan ke dalam salah satu tipe khusus (Hutagalung dkk, 2014; WHO, 2012).

Penyebab timbulnya kanker payudara belum diketahui secara pasti, namun bersifat multifaktorial atau banyak faktor (Dewi \& Hendra, 2015). Beberapa faktor yang diperkirakan mempunyai pengaruh terhadap terjadinya kanker payudara antara lain faktor umur, faktor hormon, faktor penyakit fibrokistik, faktor radiasi, faktor paritas, dan konsumsi lemak (Sulistyowati, 2012). Studi lain menyebutkan Faktor-faktor kanker payudara adalah adanya mutasi gen, ditemukannya histori (sejarah) kanker pada tingkat kekerabatan pertama, ras/ etnik, umur, umur menarche, umur pertama ketika melahirkan, adanya sejarah tumor jinak sebelumnya, estrogen exposure, breast density, radiation exposure, adanya kanker payudara di sisi payudara satunya, diet, obesitas, kurangnya aktivitas, berapa lama menyusui, dan toksin lingkungan sekitar. (Kurniati \& Putri, 2019).

Umur $>40$ tahun berisiko 13,34 kali untuk terkena tumor payudara dibandingkan dengan kelompok umur < 40 tahun (Sihombing \& Sapardin, 2014). Akan tetapi penelitian lain menunjukkan bahwa umur tidak berhubungan dengan kejadian kanker payudara. Peningkatan risiko pada umur reproduktif diduga berhubungan dengan paparan hormon estrogen dan progesterone (Yulianti et al., 2016). Semakin muda usia penderita kanker payudara semakin buruk prognosisnya (Santer dkk, 2013).

Faktor risiko lainnya terkait dengan kanker payudara adalah pekerjaan. Jenis pekerjaan yang berhubungan dengan paparan estrogen lingkungan atau zat karsinogenik di lingkungan dapat 
meningkatkan risiko kanker payudara (Karima \& Wahyono, 2013). Patogenesis yang diyakini menyebabkan hal tersebut adalah kemampuan zat karsinogenik dalam mengganggu sistem endokrin seseorang yang dapat menyebabkan beragam penyakit, termasuk kanker payudara (Lumintang dkk, 2015).

Canadian Study 2012 menunjukkan bahwa faktor risiko sebesar 42\% dimiliki oleh wanita yang bekerja di pabrik industri, yang melibatkan bahan PVC (Polyvinyl chloride). Hal ini disebabkan oleh efek karsinogenik dari zat-zat di dalamnya. Pabrik atau jenis pekerjaan yang melibatkan bahan Estrogen-like Industrial Chemical menjadi salah satu faktor risiko yang meningkatkan kejadian kanker payudara, seperti Xenoestrogen. Faktor lain yang meningkatkan risiko kanker payudara adalah pestisida, DDT (dichloro-diphenyl-trichloroethane), dieldrin, dan permetrin (Lumintang dkk, 2015; Brophy et al, 2012). Kanker payudara memiliki perilaku biologik yang sangat heterogen, sehingga diperlukan banyak parameter untuk penentuan prognostik dan terapi yang akurat. Faktor prediktif lebih menunjukkan perkiraan respon dari kanker payudara terhadap satu atau lebih modalitas pengobatan tertentu. Terdapat berbagai faktor yang dapat mempengaruhi prognostik penderita kanker payudara. Faktor-faktor tersebut terdiri dari faktor prognostik mayor dan minor. Hal-hal yang termasuk faktor prognostik mayor adalah: usia penderita, ukuran tumor, derajat keganasan, invasi vaskular, status kelenjar limfe. Faktor prognostik minor adalah: subtipe histologi, status reseptor estrogen (ER), reseptor progesteron (PR), human epidermal growth factor receptor-2 (HER-2/neu), indeks proliferasi (Ki-67), overekspresi COX-2, invasi limfovaskular, dan respon terhadap terapi Neoajuvan (Hutagalung dkk, 2014; Robbins and Kumar, 2015). Imunohistokimia (IHC) digunakan untuk mengkarakterisasi protein intraseluler atau berbagai permukaan sel di semua jaringan. Penanda individu atau lebih sering panel berbagai protein penanda dapat digunakan untuk mengkarakterisasi berbagai subtipe tumor, mengkonfirmasi jaringan asal, membedakan metastasis dari tumor primer dan memberikan informasi tambahan yang mungkin penting untuk prognosis, memprediksi respons terhadap terapi atau mengevaluasi residu pasca pengobatan tumor (Zaha, 2014).

Beberapa literatur menjelaskan, pemeriksaan terhadap gambaran histologi, derajat histologi, stadium, reseptor hormonal dan status human epidermal growth factor receptor-2 (HER2) telah dipakai sebagai standar dalam menentukan diagnosis, prognosis dan prediksi Invasive carcinoma NST payudara (Upadana \& Artha, 2014). HER-2/neu adalah salah satu gen yang paling banyak diteliti dan sangat penting untuk menentukan prognostik dari kanker payudara. Overekspresi HER-2 pada kanker payudara ditemukan 30\% dari kasus yang ada dan biasanya menunjukkan sifat metastasis tumor yang cepat dan agresif (Purwanto, et al., 2011). Tujuan penelitian ini adalah untuk mengetahui profil usia dan pekerjaan pada pasien Invasive breast carcinoma of no special type (NST) dengan fenotipe molekuler HER-2. Adapun tujuan secara khusus adalah melihat persentase sebaran hasil positif dan negatif Fenotipe molekuler Her-2 serta melihat bagaimana sebarannya berdasarkan kelompok usia dan pekerjaan pada pasien Invasive breast carcinoma of no special type (NST).

\section{METODE PENELITIAN}

Jenis penelitian ini adalah analitik observasional dengan menggunakan pendekatan cross sectional. Penelitian ini dilakukan di Laboratorium Patologi Anatomi Fakultas Kedokteran Universitas Muhammadiyah Surakarta dan sebuah Rumah Sakit di Kota Surakarta. Teknik 
pengambilan sampel yang digunakan adalah Purposive Sampling, berasal dari 106 wanita etnis Jawa, dengan pemeriksaan patologi anatomi menunjukkan karsinoma payudara invasif tipe NST dan memiliki hasil pemeriksaan HER2. Adapun contoh hasil pembacaan Her-2 sebagai berikut:

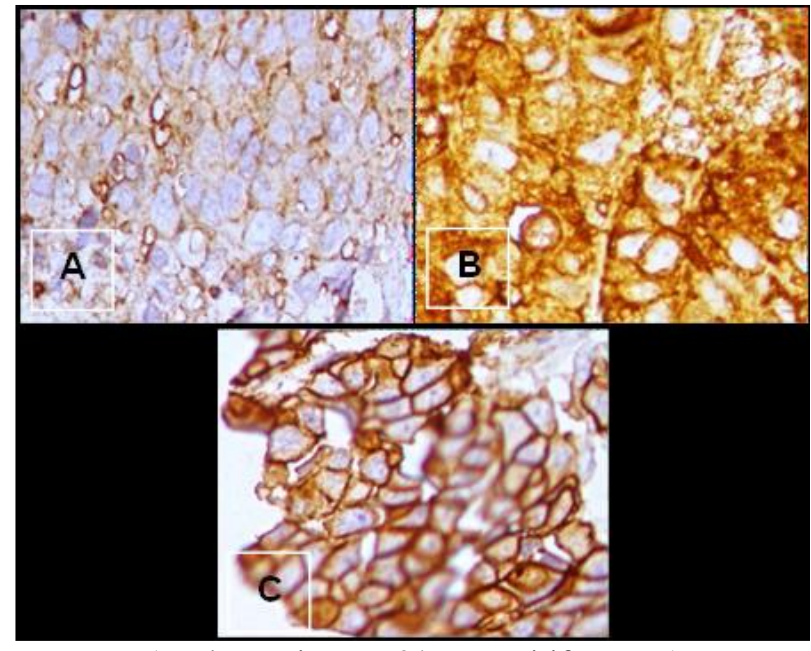

A. Ekspresi HER-2/neu positif score 1,

B. Ekspresi HER-2/neu positif score 2,

C. Ekspresi HER-2/neu positif score 3,

(Hutagalung dkk, 2014)

Gambar 1. Contoh Penilaian Ekspresi HER-2 Positif (100x)

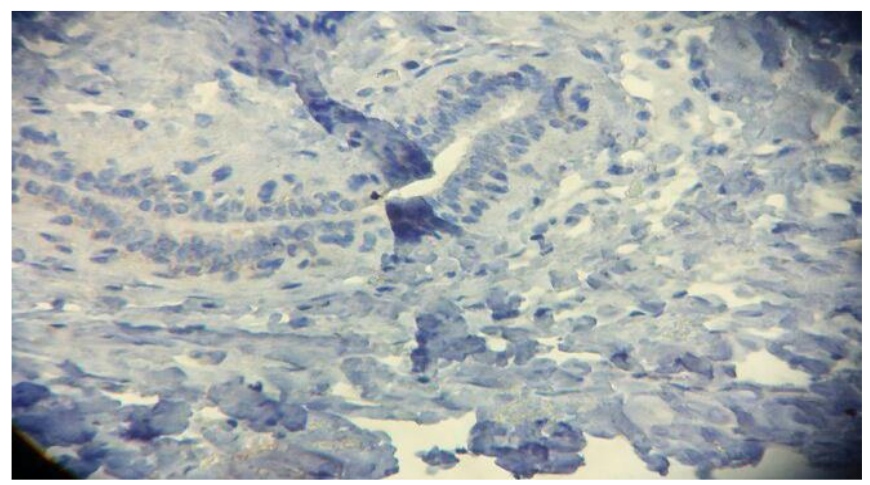

(Hatem et al., 2016)

Gambar 2. Contoh Penilaian Ekspresi HER-2 Negatif (40x ) 


\section{HASIL DAN PEMBAHASAN}

Penelitian ini meneliti tentang profil usia dan pekerjaan berdasarkan fenotipe molekuler HER-2 pada pasien Invasive breast carcinoma of no special type (NST) yang dilakukan pada bulan November sampai Desember 2017 sejumlah 106 sampel. Hasil penelitian demografik dan karakteristik sampel penelitian dapat dilihat pada tabel yang disajikan berikut.

\subsection{Karakteristik Variabel Hasil Penelitian}

Tabel 1. Karakteristik sampel berdasarkan fenotipe molekuler HER-2

\begin{tabular}{crr}
\hline Karakteristik & HER-2 $(+)$ & $\begin{array}{l}\text { HER-2 }(-) \\
\mathrm{n}=53(\%)\end{array}$ \\
\hline Usia & & \\
$<50$ Tahun & $22(48,9)$ & $23(51,1)$ \\
$\geq 50$ Tahun & $31(50,8)$ & $30(49,2)$ \\
Pekerjaan & & \\
Berisiko rendah & $27(42,2)$ & $37(57,8)$ \\
Berisiko tinggi & $26(61,9)$ & $16(38,1)$ \\
Tingkat pendidikan & & \\
Dasar & $12(41,4)$ & $17(58,6)$ \\
Menengah & $28(49,1)$ & $29(50,9)$ \\
Tinggi & $13(65)$ & $7(35)$ \\
Tempat tinggal & & \\
Urban & $36(52,2)$ & $33(47,8)$ \\
Rural & $17(45,9)$ & $20(54,1)$ \\
\hline
\end{tabular}

(Sumber : Data primer, 2017)

Berdasarkan Tabel 1 didapatkan bahwa usia terbanyak pasien kanker payudara yaitu $\geq 50$ tahun sebanyak 61 sampel, dimana 50,8\% sampel memiliki subtipe molekuler HER-2 positif. Hasil penelitian sebelumnya juga menyebutkan bahwa 58\% kejadian kanker payudara terjadi pada wanita dengan usia diatas 50 tahun (Laamiri, et al., 2015). Penelitian lainnya juga menyebutkan bahwa risiko kanker payudara meningkat seiring dengan bertambahnya usia (Lumintang dkk, 2015). Usia tua lebih berpotensi untuk terserang kanker payudara dari usia muda. Seorang wanita yang berusia 50 tahun $8 \mathrm{x}$ lipat lebih berpeluang untuk terserang kanker payudara dibandingkan dengan wanita yang berusia 30 tahun (Sulistyowati, 2012). Sekitar $48 \%$ insiden kanker payudara terjadi pada perempuan berusia lebih dari 65 tahun dan $30 \%$ pada perempuan berusia lebih dari 70 tahun (Rahmatya dkk, 2015).

Dilihat dari karakteristik pekerjaan menunjukkan bahwa kategori pekerjaan terbanyak dari sampel penelitian ini adalah pekerjaan berisiko rendah, yaitu sebanyak 64 sampel. Sejumlah 37 sampel $(57,8 \%)$ dengan pekerjaan berisiko rendah memiliki subtipe molekuler HER-2 negatif. Jenis pekerjaan yang termasuk di dalam kategori pekerjaan rendah yaitu Ibu Rumah Tangga (IRT). Hal ini sesuai dengan penelitian Karima et al (2013) didapatkan bahwa sebagian besar pasien kanker payudara memiliki pekerjaan sebagai IRT, yaitu sebanyak 82,9\% (Karima \& Wahyono, 2013).

Karakteristik sampel yang juga terdapat dalam penelitian ini yaitu tingkat pendidikan. Didapatkan bahwa jumlah sampel terbanyak memiliki tingkat pendidikan menengah sebanyak 57 
sampel. Hasil penelitian ini juga sejalan dengan penelitian Karima dengan hasil jumlah sampel yang memiliki tingkat pendidikan menengah sebanyak $58,1 \%$ dari total sampel (Karima \& Wahyono, 2013).

Berdasarkan tempat tinggal sampel, dapat dilihat bahwa sebagian besar sampel bertempat tinggal di area urban, yaitu 69 sampel $(65,1 \%)$. Hal ini menunjukkan adanya kemungkinan paparan tingkat karsinogen yang tinggi. Hal ini sesuai dengan hasil penelitian Wen di China yang juga menunjukkan bahwa pasien kanker payudara banyak bertempat tinggal di area urban (Wen et al, 2016).

\subsection{Hubungan Usia Dengan Fenotipe Molekuler HER-2}

Usia telah berulang kali diidentifikasi sebagai faktor prognostik penting pada kanker payudara. Penelitian sebelumnya menyebutkan bahwa di Amerika pada tahun 2003 usia rata-rata wanita yang terkena kanker payudara yaitu 63 tahun. Wanita muda yang menderita kanker payudara memiliki ketahanan hidup yang lebih buruk dan dua kali lebih mungkin mengalami kekambuhan bila dibandingkan dengan pasien yang lebih tua dengan stadium serupa (Wei et al, 2010).

Sampel yang diteliti sebanyak 106 sampel menunjukkan rentang usia pasien dengan kasus Invasive breast carcinoma of no special type (NST) antara 25 hingga 82 tahun. Data tersebut sesuai dengan gambaran data dari hasil penelitian Mukti yang menyatakan bahwa usia yang menjadi faktor resiko penderita kanker payudara ialah antara usia 20-74 tahun. Proporsi faktor resiko usia dibagi dalam dua kategori, usia produktif 20-49 tahun, sedangkan usia menopause 50-74 tahun. Proporsi jumlah pasien yang menderita kanker payudara pada usia produktif adalah sebesar 49,39 $\%$, sedangkan usia menopause sebanyak 50,61 \%. Pada penelitian ini diketahui bahwa proporsi jumlah pasien kanker payudara yang telah melakukan pemeriksaan yakni usia produktif (31-49 tahun) terdapat 45 kasus $(42,5 \%)$, sedangkan usia menopause (di atas 50) terdapat 61 kasus $(57,5$ $\%$ ). Sehingga dapat dikatakan bahwa data rekam medis yang diperoleh ini sejalan dengan penelitian yang dilakukan (Mukti et al, 2016).

Hasil penelitian menunjukkan bahwa HER-2 positif paling banyak ditemukan pada Invasive breast carcinoma of no special type (NST) dengan usia $\geq 50$ tahun yaitu sebanyak 31 kasus atau 50,8\%, kemudian usia $<50$ tahun sebanyak 30 kasus (49,2\%). Sebuah penelitian yang dilakukan di RSUP Sanglah oleh Wijaya dan kawan-kawan, memberikan hasil yang berbeda dengan penilitian ini mengenai proporsi usia terbanyak kejadian kanker payudara. Didapatkan angka kejadian kanker payudara terbanyak berdasarkan usia yaitu pada wanita usia produktif, < 50 tahun. Hasil analisis statistik dengan menggunakan chi-square test mengenai hubungan usia dengan subtipe molekuler HER2 pada penelitian Wijaya dan kawan-kawan memberikan nilai $\mathrm{p}>$ 0,05 yang berarti dari penelitian tersebut juga didapatkan bahwa tidak ada hubungan yang bermakna antara ekspresi human epidermal receptor 2 dengan usia (Wijaya \& Manuaba, 2017). 


\subsection{Hubungan pekerjaan dengan fenotipe molekuler HER-2}

Jenis pekerjaan sebagai salah satu elemen dari faktor sosial demografi, dapat meningkatkan risiko kanker payudara. Risiko tersebut berhubungan dengan paparan estrogen lingkungan atau zat karsinogenik di lingkungan. Wanita yang tidak bekerja/ Ibu Rumah Tangga diasumsikan tidak terpapar oleh zat-zat karsinogen dari tempat kerja. Wanita yang bekerja sebagai PNS/ Pegawai Swasta/ Wiraswasta diasumsikan lebih cenderung terpapar oleh zat-zat karsinogen daripada wanita yang tidak bekerja/ IRT. Kelompok yang paling mempunyai kecenderungan terpapar oleh zat-zat karsinogen diasumsikan adalah wanita yang bekerja sebagai petani/ buruh (Karima \& Wahyono, 2013). Paparan kerja shift malam merupakan risiko pekerjaan paling signifikan yang terkait dengan kanker payudara dan telah diklasifikasikan sebagai karsinogen oleh IARC (Badan Internasional untuk Penelitian Kanker). Beberapa penelitian di kalangan perawat telah mengindikasikan bahwa populasi ini memiliki risiko lebih tinggi terkena kanker payudara dibandingkan dengan populasi wanita secara umum, yang menunjukkan hubungan erat antara pendudukan dan perkembangan kanker (Fenga, 2016). Hasil penelitian di Kanada dan Inggris menunjukkan bahwa pekerjaan industrial dapat meningkatkan risiko kejadian kanker payudara (Brophy et al 2012; Lumintang dkk, 2015)

Penelitian di Jakarta yang dilakukan oleh Karima menyebutkan bahwa jenis pekerjaan merupakan salah satu dari faktor sosial demografi yang dapat meningkatkan risiko kanker payudara. Hal ini berkaitan dengan paparan estrogen lingkungan atau zat karsinogenik di lingkungan. Sejumlah penelitian menunjukkan adanya peningkatan risiko kanker payudara pada wanita yang terpajan polycyclic aromatic hydrocarbons (PAH), beberapa pelarut, pestisida, logam, industri kimia dan tekstil (Karima et al, 2013). Pertumbuhan risiko kanker payudara juga diamati pada wanita yang dipekerjakan di industri farmasi, produksi kosmetik, penata rambut, perawat, teknisi laboratorium, ahli kebersihan gigi dan produksi mobil. (Pranjic et al, 2014)

Penelitian sebelumnya di Italia mengungkap mengenai hubungan antara kerja shift malam dan morbiditas kanker payudara. Paparan cahaya di malam hari dapat menekan puncak produksi melatonin dan jam sirkadian utama, mengakibatkan terjadinya gangguan tidur yang dapat memberi efek negatif pada sistem kekebalan tubuh. Peningkatan penggunaan penerangan listrik di malam hari dapat mengubah homeostasis melatonin dan berkontribusi pada kanker payudara (WHO, 2012). Melatonin dapat bertindak dalam inisiasi, promosi dan pengembangan tumor. Selanjutnya, melatonin bertindak sebagai pengubah respons terhadap estrogen: i) Mengeluarkan efek antiestrogenik dengan interaksi dengan reseptor estrogen $\alpha(E R \alpha)$; ii) menetralkan efek estradiol pada proliferasi sel kanker payudara, invasiveness dan aktivitas telomerase; iii) menurunkan ekspresi faktor pertumbuhan protein dan proto-onkogen yang distimulasi oleh estrogen; dan iv) menekan human epidermal growth factor receptor 2/ HER2 (WHO, 2012).

Jumlah penderita kanker payudara ditinjau dari jenis pekerjaan lebih banyak dijumpai pada pasien dengan kategori pekerjaan berisiko rendah termasuk di dalamnya ibu rumah tangga, yaitu berjumlah 64 sampel. Hasil penelitian ini sesuai dengan hasil penelitian di Surabaya dan Malaysia (Dewi dan Hendra, 2015 ; Norsa'adah et al, 2011). Penelitian Liu memberikan temuan bahwa pendidikan juga berhubungan dengan pekerjaan seseorang yang menggambarkan sosial ekonomi dari sampel. Hal ini berkaitan dengan pendapatan, dimana mereka yang berpendapatan rendah 
berpengaruh terhadap saat kedatangannya untuk berobat dan terdiagnosa. Keterlambatan dalam diagnosa berhubungan dengan tingkat keparahan dari suatu penyakit (Liu et al, 2017).

Penelitian ini memiliki keterbatasan dalam mengidentifikasi riwayat dan berapa lama jenis pekerjaan yang tertera, karena berdasarkan data sekunder yang didapatkan dari rekam medis.

\section{SIMPULAN}

Usia terbanyak pasien kanker payudara yaitu $\geq 50$ tahun sebanyak 61 sampel, dimana 50,8\% sampel memiliki subtipe molekuler HER-2 positif. Proporsi jumlah pasien kanker payudara yakni usia produktif (31-49 tahun) terdapat 45 kasus (42,5\%), sedangkan usia menopause (di atas 50) terdapat 61 kasus $(57,5 \%)$.

Kategori pekerjaan terbanyak dari sampel penelitian ini adalah pekerjaan berisiko rendah, yaitu sebanyak 64 sampel. Jenis pekerjaan yang termasuk di dalam kategori pekerjaan beresiko rendah yaitu Ibu Rumah Tangga (IRT). Sejumlah 37 sampel (57,8\%) dengan pekerjaan berisiko rendah memiliki subtipe molekuler HER-2 negatif.

\section{SARAN}

Berdasarkan hasil penelitian saran untuk wanita yang sudah memasuki usia produktif untuk melakukan deteksi dini adanya tanda dan gejala kanker payudara secara teratur agar tidak terjadi keterlambatan dalam penanganan.

\section{REFERENSI}

Anders, C. K., Johnson, R., Litton, J., Phillips, M., Archie, B. (2010). Breast Cancer before Age 40 Years. Semin Oncol. 1-24. 2010

Allen P, (2016). “Age Categories and Life Cycle Groupings - Statistics Canada,” 2016.

Anggorowati, L. (2013).Faktor Risiko Kanker Payudara Wanita. Kemas. 2: 102-8

Assi, H. A., Khoury, K. E., Dbouk, H., Khalil, L. E., Mouhieddine, T. H., El Saghir, N. S. (2010). Epidemiology and Prognosis of Breast Cancer in Young Women. J Thorac Dis. 5: 1-7. 2013

Balekouzou, A., Yin, P., Afewerky, H. K., Bekolo, C., Pamatika, C. M., Nambei, S. W. (2017). Behavioral Risk Factors of Breast Cancer in Bangui of Central African Republic: a Retrospektif Case-control Study. PLoS ONE. 1-16. 2017

Bray F, Ferlay J, Soerjomataram I, Siegel R, torre L, Jemal A. (2018).Global Cancer Statistics 2018. American Cancer Society Journals. September 2018

Brophy, J. T., Keith, M. M., Watterson, A., Park, R., Gilbertson, M., Maticka-Tyndale, E. (2012). Breast Cancer Risk in Relation to Occupations with Exposure to Carcinogens and Endocrine Disruptors: a Canadian Case-control. Environ Health. 1-17. 2012

Cancer Research. (2016). Breast Cancer. UK. 1-3. 2016. 
Damodaran, S., Olson, E. M. (2013).Targeting the Human Epidermal Growth Factor 2 Pathway in Breast Cancer. Hosp Pract. 1-14. 2013

Data Riset Kesehatan Dasar. (2015). Stop Kanker. Badan Litbangkes Kementerian Kesehatan RI.

Dewi, G. A. T, Hendra, L. Y. (2015). Analisis Risiko Kanker Payudara Berdasar Riwayat Pemakaian Kontrasepsi Hormonal dan Usia Menarche. JBE. 3(1) : 12-23.

Fenga, C. (2016). Occupational Exposure and Risk of Breast Cancer (Review). Biomed Rep. 4: 282-92.

Gardstein B. M., K. Rokho dan L. K. Davis. (2003). "Occupation as a Risk Factor for Breast Cancer among Women in Massachusetts 1982-1992,”. 2003

Ghani L, (2009). “Seluk Beluk Menopause,” Media Penelit. dan Pengembang. Kesehat., vol. 19, pp. 193-7, 2009.

Global Facts and Figures.(2015). American Cancer Society. 3rd edition. America.

Hatem, S. F., Alyaqubi, K. J., Al-Atrooshi, S. A., Alsayyid, M. M., Saad, M., Safaa, (2016). R. The Study of HER-2/neu, ER/PR Expression Using Immunohistochemistry (IHC) in the Iraqi Breast Cancer. J Vet Met Sci. 7: 18-27. 2016

Hutagalung, S. B., Mulyadi, I. K., Artha, I.G (2014). Ekspresi Ki-67 dan HER-2/neu Berhubungan dengan Derajat Histopatologik Kanker Payudara Invasive No Special Type (NST). Indones J Pathol. 23: 45-50.

Iqbal, N., Iqbal, N. (2014). Human Epidermal Growth Factor Receptor 2 (HER2) in Cancers: Overexpression and Therapeutic Implications. Mol Biol Int. 1-10. 2014

Irwan, Azamris, Bachtiar, H. (2015). Perbandingan Prognosis Subtipe Molekuler Kanker Payudara antara Pasien Kanker Payudara Wanita Usia Muda dan Tua di RSUP Dr. M. Djamil Padang. MKA. 38: 208-17. 2015

Karima, U. Q., Wahyono, T. Y. (2013). Faktor-Faktor yang Berhubungan dengan Kejadian Kanker Payudara Wanita di Rumah Sakit Umum Pusat Nasional (RSUPN) Dr. Cipto Mangunkusumo Jakarta tahun 2013. 1-20.

Kullberg, C., Selander, J., Albin, M., Borgquist, S., Manjer, J., Gustavsson, P. (2017). Female White-collar Workers Remain at Higher Risk of breast Cancer after Adjustments for Individual Risk Factors Related to Reproduction and Lifestyle. Occup Environ Med. 1-7. 2017

Kurniati YP, Amarwati S, Sadhana U, Puspasari D. (2017). Gambaran Histopatologi Ekspresi Interferon Gamma $(\gamma)$ pada Fibroadenoma Mammae (FAM) dan Invasive No Special Type (NST) Breast Carcinoma. Biomedika vol 9 No 2.

Kurniati YP and Putri MP. (2019). The Molecular Phenotype Of Human Epidermal Growth Factor Receptor2 Java Ethnic Based On Body Mass Index In Breast cancer. International Conference on Pharmaceutical Updates.

Labellapansa, A., Muhimmah, I., Indrayanti. (2013). Klasifikasi Citra Imunohistokimia Sel Kanker Payudara HER2 Skore 1+ dan 3+. SNIMed. 24-30. 2013 
Laamiri, F. Z., Bouayad, A., Hasswane, N., Ahid, S., Mrabet, M., Amina B. (2015). Risk Factors for Breast Cancer of Different Age Groups: Moroccan Data?. OJOG. 5: 79-87. 2015

Liu, Y., Zhang, J., Huang, R.,Feng, W., Kong, Y., Xu, F., Zhao, L., Shong, Q. (2017). Influence of Occupation and Education Level on Breast Cancer Stage at Diagnosis, and Treatment

Lumintang, L. M., Susanto, A., Gadri, R.. (2015). Djatmiko, A. Profil Pasien Kanker Payudara di Rumah Sakit Onkologi Surabaya, 2014. Indones J Cancer. 105-10.

Manik, N. T., Maryati, I., Ermiati. (2012). Riwayat Gaya Hidup Penderita Kanker Payudara di Rumah Sakit Umum Daerah Kota Sumedang. 1-16. 2012

Moasser, M. M. (2011).The Oncogen Her2; its Signaling and Transforming Functions and its Role in Human Cancer Pathogenesis. Oncogene. 1-32. 2011

Mukti, A. F. R., Bekti, R. S., Roebijoso, J. (2016). Korelasi Pemeriksaan Human Epidermal Growth Factor Receptor-2 (HER-2) denga Stadium Klinis TNM pada Pasien Kanker Payudaradi Instalasi Patologi Anatomi RS dr. Saiful Anwar Periode Januari 2010Desember 2012. Majalah Kesehatan FKUB. 3: 112-120. 2016

Nani, D. (2009). Analisis Faktor-Faktor yang Berhubungan dengan Kejadian Kanker Payudara di Rumah Sakit Pertamina Cilacap. JKS. 61-6. 2009

Norsa'adah, B., Rampal. K. G.,Rahmah, M. A., Naing, N. N., Biswal, B. M. (2011). Diagnosis Delay of Breast Cancer and Its Associated Factors in Malaysian Women. BMC Cancer. 11: 1-8. 2011

Pranjic, N., Gledo, I., Males-Bilic, L. (2014). The Most Common New Cases of Breast Cancer among the Housewives: The SomeCarcinogenic Determinant. 7(2): 344-349. 2014

Price, S. A., Wilson, L. M. (2005). Patofisiologi: Konsep Klinis Proses-Proses Penyakit. 6th edition. Jakarta: EGC. 2005

Priyatin, C., Ulfiana, E., Sumarni, S. (2013). Faktor Risiko yang Berpengaruh terhadap Kejadian Kanker Payudara di RSUP Dr. Kariadi Semarang. JK. 9-19. 2013

Purwanto, I., Kurnianda, J., Hariadi, K. W., Harijadi, Aryandono, T., Setiaji, K. (2011) Concentration of Serum HER-2/Neu as a Prognostic Factor in Locally Advanced Breast Cancer (LABC) and Metastatic Breast Cancer (MBC). Indones J Intern Med. 23-8. 2011

Rahmatya, A., Khambri, D., Mulyani, H. (2015). Hubungan Usia dengan Gambaran Klinikopatologi Kanker Payudara di Bagian Bedah Dr. M. Djamil Padang. JKA. 478-84. 2015option in China. Med. 1-9. 2017

Rimawi, M. F., Shetty, P. B., Weiss, H. L., Schiff, R., Osbome, C. K., Chamness, G. C.(2010). Epidermal Growth Factor Receptor Expression in Breast Cancer Association with Biologic Phenotype and Clinical Outcomes. Cancer. 1234-42.

Robbins, Kumar. (2015). Pathologic Basic of Disease. 9th edition. Philadelphi: Saunders, Elsevier. 2015.

Romadhon, Y.A. (2013). Gangguan Siklus Sel dan Mutasi Gen pada Kanker Payudara. CDK. 10: 786-9. 
Rosai, J. Rosai and Ackerman's Surgical Pathology. 10th edition.Philadelphia: Saunders, Elsevier. 2011

Samsiah. (2016). Faktor-Faktor yang Mempengaruhi Penguasaan Aspek Bilangan pada Guru SD Negeri di Kecamatan Pangkajene Kabupaten Pangkep. Sainsmat. 5: 125-36. 2016

Santer., Siregar, K.B., Suyatno. (2013). Profil Ekspresi HER2 dan Ki67 pada Berbagai Kelompok Usia Penderita Kanker Payudara di RSUP H. Adam Malik Medan. J Med Sch. 46(3) : 1-4.

Sihombing, M., \& Sapardin, N. (2014). The risk factors of breast tumor among women aged 2565 years old in five villages of Bogor Tengah district. Pusat Teknologi Terapan Kesehatan Dan Epidemiologi Klinik, Badan Penelitian Dan Pengembangan, Kementerian Kesehatan RI, 1(1), 1-10. https://media.neliti.com/media/publications/106367-ID-faktor-risikotumor-payudara-pada-peremp.pdf

Statistics South Africa.Census 2001: Stages in the Life Cycle of South Africans. Africa. 2005

Sulistiyowati. (2012). Stadium Kanker Payudara Ditinjau dari Usia dan Paritas Ibu di Unit Rawat Jalan RSUD Dr. Soegiri Kabupaten Lamongan. 3(13) : 9-15.

Tai, W., Mahato, R., Cheng, K. (2011). The Role of HER2 in Cancer Therapy and Targetes Drug Delivery. J Control Release. 1-28. 2011

Upadana, I. N., Artha, I. G. (2014). Hubungan Ekspresi Cyclooxygenase-2, Reseptor Estrogen dan Derajat Histologi Invasive Carcinoma of No Special Type Payudara. Indones J Pathol. 6-10. 2014

Wei, R., Lau. S. S. S., Cheung, P. S. Y. (2010). Breast Carcinoma in Chinese Women: Does Age Affect Treatment Choice and Outcome?. Asian J Surg. 33 (2): 97-102. 2010

Wen, D., He, Y., Wei, L., Zhang,N., Li,S., Wen, X., Yang, Y., Wang, G., Wang,S., Geng,C., Liu,Y., Shan,B. (2016). Incidance Rate of Female Breast Cancer in Urban Shijiazhuang in 2012 and Modifiable Risk Factors. Thor Cancer. 7: 522-529. 2016

Wijaya, I. G. C. P., Manuaba, I. B. T. W. (2014). Hubungan Subtipe Imunohistokimia dengan Usia pada Pasien Kanker Payudara di RSUP Sanglah Kota Denpasar. E-Jurnal Medika. 6: 1-5. 2017

WHO. (2012). Classification of Tumours of the Breast. 4th edition. Lyon.

Yan B, L.-M. Yang, L.-P. Hao, C. Yang, L. Quan, L.-H. Wang, Z. Wu, X.-P. Li, Y.-T. Gao, Q. Sun dan J.-M. Yuan, (2016). "Determinants of Quality of Life for Breast Cancer Patients in Shanghai, China," 2016.

Yulianti, I., Santoso, H., \& Sutinigsih, D. (2016). Faktor-Faktor Risiko Kanker Payudara (Studi Kasus Pada Rumah Sakit Ken Saras Semarang). Jurnal Kesehatan Masyarakat Universitas Diponegoro, 4(4), 401-409.

Zaha D. C. (2014). "Significance of immunohistochemistry in breast cancer," World J Clin Oncol, pp. 382-91. 2014 